\title{
Dietary patterns and risk of asthma: results from three countries in European Community Respiratory Health Survey-II
}

\author{
Richard Hooper ${ }^{1}$, Joachim Heinrich ${ }^{2}$, Ernst Omenaas ${ }^{3}$, Stefanie Sausenthaler ${ }^{2}$, Vanessa Garcia-Larsen ${ }^{1}$, \\ Ioannis Bakolis ${ }^{1}$ and Peter Burney ${ }^{1}$ \\ ${ }^{1}$ Respiratory Epidemiology and Public Health Group, Imperial College, National Heart and Lung Institute, Emmanuel Kaye \\ Building, Manresa Road, London SW3 6LR, UK \\ ${ }^{2}$ Institute of Epidemiology, Helmholtz Zentrum München, Neuherberg, Germany \\ ${ }^{3}$ Centre for Clinical Research, Haukeland University Hospital, Bergen, Norway
}

(Received 15 May 2009 - Revised 14 October 2009 - Accepted 21 October 2009 - First published online 9 December 2009)

Dietary patterns offer an alternative to the analysis of individual foods or nutrients in nutritional epidemiological studies. The aim of the present study was to identify dietary patterns common to different European countries and examine their associations with asthma. In five study centres (two in Germany, two in the UK and one in Norway), 1174 adults aged 29-55 years completed a FFQ and respiratory symptoms questionnaire. A meta-analytic approach was used to identify the dietary patterns and analyse them in relation to current asthma, asthma symptoms and bronchial responsiveness (BHR). Two patterns emerged, generally correlating with the same foods at different centres: one associated with intake of meats and potatoes; the other with fish, fruits and vegetables. There was no evidence that the fish, fruits and vegetables pattern was associated with asthma (OR 1.11 (95\% CI 0.93, 1.33)), symptom score (ratio of means $1.07(0.98,1.17)$ ) or BHR (regression coefficient $-0.01(-0.12$, $0 \cdot 10)$ ), though these CI appeared to rule out large protective effects of consuming these foods. There was no overall evidence that the meat and potato pattern was associated with asthma (OR 1.02 $(0.79,1.31)$ ), symptom score (ratio of means 1.07 (0.84, 1.36)) or BHR (regression coefficient $-0.08(-0.27,0 \cdot 10)$ ), but there was heterogeneity between centres in the association with symptom score: a negative association at the two German centres; a positive association at the others. Heterogeneity in a multi-centre observational study of diet could suggest alternative explanations for apparent effects of diet, such as uncontrolled confounding.

Asthma: Bronchial responsiveness: Dietary patterns: Meta-analysis

There is accumulating evidence that diet affects the prevalence of asthma, for example via the protective effects of dietary antioxidants ${ }^{(1)}$ and $n-3$ PUFA in oily fish ${ }^{(2)}$. Interpreting the evidence from observational nutritional studies is difficult, however, because of the wide potential for confounding and effect modification. The results of trials are often inconclusive or contradictory ${ }^{(3)}$. Statistical analysis can deal with questions of confounding and interaction of dietary exposures to some extent, but the sheer number of features of diet that can be measured will often defeat comprehensive investigation. An alternative approach is to extract a small number of dietary 'patterns' using data-analytic methods, such as principal components analysis $(\mathrm{PCA})^{(4)}$. This approach is now routinely applied to FFQ data, though applications in respiratory epidemiology have so far been scarce. Prospective cohort studies of US men and women have found that a diet rich in refined grains, cured and red meats, desserts and French fries is positively associated with risk of chronic obstructive pulmonary disease, and a diet rich in fruits, vegetables and fish is negatively associated ${ }^{(5,6)}$. Dietary patterns were not associated with adult-onset asthma in these cohorts. A study of Chinese Singaporeans found that a diet rich in meats, $\mathrm{Na}$ and refined carbohydrates was positively associated with habitual cough and phlegm ${ }^{(7)}$, while a study of Japanese female students found that a butter and rapeseed oil dietary pattern, and a fast-food, soft drink and juice dietary pattern were both positively associated with wheeze ${ }^{(8)}$. In France, a study of female teachers found that a pastry, processed meat and dessert pattern was positively associated with reporting frequent asthma attacks, and a nut and wine pattern was negatively associated ${ }^{(9)}$. One problem with the PCA approach is that it does not lend itself well to the synthesis of evidence from different studies. Indeed, there is no a priori guarantee that the same patterns will be seen in different countries with differing culinary traditions and sources for foods.

In the present study, we looked at dietary patterns in three countries participating in the European Community Respiratory Health Survey (ECRHS) and used these to investigate relationships between diet and asthma in adults.

Abbreviations: BHR, bronchial responsiveness; ECRHS, European Community Respiratory Health Survey; EPIC, European Prospective Investigation into Cancer and Nutrition; $\mathrm{FEV}_{1}$, forced expiratory volume in $1 \mathrm{~s}$; PCA, principal components analysis.

* Corresponding author: Dr Richard Hooper, fax +44020 7351 8322, email richard.hooper2@imperial.ac.uk 
We derived the dietary patterns using a meta-analytic approach to PCA which, to our knowledge, has not previously been used in the analysis of FFQ data.

\section{Material and methods}

\section{Study design and population}

The design of ECRHS has been described in detail elsewhere $^{(10)}$. ECRHS-I ran from 1990 to 1995 . At each centre, a random sample of at least 3000 adults aged 20-44 years was selected using a local sampling frame. From those who responded, a random sample of at least 600 adults was selected to undergo a detailed clinical examination. Eight to ten years later, these subjects were contacted to take part in a follow-up study (ECRHS-II) and invited to a local clinic for further assessments, including an interviewer-administered questionnaire. The sample size at each centre was sufficient for comparing changes in prevalence of wheezing, asthma and atopy between centres ${ }^{(10)}$.

Dietary assessments were included in ECRHS-II at some centres, though the method and protocol differed between countries. In the present paper, we report results from five centres in three countries in ECRHS-II, where FFQ were administered: Hamburg and Erfurt in Germany; Ipswich and Norwich in the UK; Bergen in Norway. Three thousand three hundred and eighty-seven adults at these centres were contacted to take part in ECRHS-II.

\section{Respiratory outcomes}

Questions on asthma and respiratory symptoms were taken from the bronchial symptoms questions of the International Union against Tuberculosis and Lung Disease questionnaire ${ }^{(10)}$. Current asthma was defined as an attack of asthma or being woken by an attack of shortness of breath in the last 12 months or currently taking any medicines for asthma. Five questions on symptoms in the last 12 months (breathless when wheezing, woken with tightness in chest, shortness of breath while at rest, shortness of breath after exercise, woken by shortness of breath) were used to construct an asthma symptom score on a five-point scale ${ }^{(11)}$.

Bronchial responsiveness (BHR) was assessed using a methacholine challenge. For safety reasons, the challenge was not carried out on participants whose forced expiratory volume in $1 \mathrm{~s}\left(\mathrm{FEV}_{1}\right)$ was $<70 \%$ of their predicted value or $<1.5$ litres. The outcome referred to here as BHR 'slope' is $100 /(\log$ slope +10$)$, where log slope is calculated by regressing percentage fall in $\mathrm{FEV}_{1}$ on $\log _{10}$ dose $\mathrm{e}^{(12)}$. A low 'slope' is indicative of high BHR. To help to assess the impact of having missing slope for low $\mathrm{FEV}_{1}$ values, $\mathrm{FEV}_{1}$ was also analysed as a separate outcome.

\section{FFQ}

The German FFQ was developed for use in the German part of the European Prospective Investigation into Cancer and Nutrition (EPIC-Heidelberg) ${ }^{(13)}$. It recorded a consumption of 158 different foods over the last 12 months as frequencies from never to five portions a day or more. Portion size was selected from a multiple choice, sometimes with reference photos. Supplementary questions covered aspects of diet, such as the preparation and fat content of foods. The FFQ was distributed after the clinical and questionnaire assessments, and the participants were asked to return the completed FFQ by mail.

The UK FFQ was adapted from one developed for EPIC-UK. It recorded a consumption of 198 different foods over the last 12 months as frequencies (from never to $7 \mathrm{~d}$ a week) and number of portions consumed on each of these days (portions being defined on the questionnaire). As on the German FFQ, there were also supplementary questions. The Norwegian FFQ was a translation of the UK FFQ, but contained six additional foods not appearing on the UK questionnaire. In Norway, the FFQ was administered at the same clinic visit as the other assessments in ECRHS-II; while in the UK, participants were invited to attend the clinic on a separate occasion to complete the FFQ. In each case, the FFQ was self-completed and checked in the clinic by one of the local research team to cut down on missing data.

Food frequencies were converted to intakes in $\mathrm{g} / \mathrm{d}$. In the UK and Norway, this used portion weights from the standard UK reference ${ }^{(14)}$, while in Germany portion sizes were those used with the EPIC FFQ ${ }^{(13)}$. For a few foods, such as butter, intake was calculated both from the reported food frequency and the supplementary questions on food preparation and cooking.

\section{Nutrient intakes}

Nutrient intakes were calculated in each country from FFQ data and supplementary questions, using local food tables $^{(15-17)}$. Because the Norwegian FFQ was originally translated from the UK FFQ, it contained a number of foods not commonly eaten in Norway, hence not included in the Norwegian food tables; UK references were used for these foods where they did occur.

\section{Exclusions of dietary data}

On the UK FFQ and Norwegian FFQ, respondents sometimes left individual items blank. This was assumed to denote zero intakes of these foods unless more than $20 \%$ of items were blank, in which case the FFQ was considered incomplete, and the subject was excluded from analyses. Subjects in each country were also excluded if they had extreme values of total energy intake which might suggest an unrealistic response: we calculated expected BMR with given age, weight and sex ${ }^{(18)}$, and excluded subjects with a ratio of energy intake to expected BMR below the $0 \cdot 5$ th sample centile or above the 99.5 th sample centile for their country ${ }^{(19)}$.

\section{Validity and repeatability of $F F Q$}

Validity and repeatability of the German FFQ were assessed in 104 men and women aged 35-64 years as part of a pilot for the EPIC study ${ }^{(13)}$. The FFQ was administered on two occasions in the interval of 6 months. Twelve 24-h dietary recalls applied at monthly intervals served as the reference for the validity of the second FFQ assessment.

Repeatability of the UK FFQ was assessed in eighty-two adults (sixty-six from the sample described in the present 
paper and sixteen others with asthma symptoms), using two assessments separated by an interval of 5-23 months. Validity of the UK FFQ was assessed in 263 adults (206 from the sample described in the present paper and 57 others with asthma symptoms), using a single 24-h dietary recall. The Norwegian FFQ was not assessed for repeatability or validity.

Validity and repeatability are summarised in Table 1.

\section{Dietary patterns}

Some aggregation of food items on each country's FFQ was necessary to allow intakes to be matched across questionnaires, for example, on the UK FFQ and Norwegian FFQ fried egg was aggregated with omelette or scrambled egg to allow comparison with the German FFQ, which simply recorded intake of fried egg, omelette or scrambled egg. We performed the minimum aggregation necessary to allow foods to be matched. This process led to a list of seventy-four foods or food groups whose intake in $\mathrm{g} / \mathrm{d}$ was available in all three countries (see the Appendix). Aggregation of food items into broader, a priori groupings (often fewer than we have used) is commonplace in the analysis of $\mathrm{FFQ}^{(5,6,20)}$.

In each centre, we evaluated the correlation matrix of foods on our list and pooled the correlations from different centres using the method of Rosenthal ${ }^{(21)}$. Specifically, each correlation coefficient was transformed using a Fisher transformation $(0.5 \log ((1+r) /(1-r)))$ to give it an approximately normal sampling distribution with variance $1 /(n-3)$, where $n$ is the sample size for that centre. A weighted average of these values was then calculated, in which each value was given a weight proportional to the inverse of its variance (analogous to pooling estimates of a mean, say, from subsamples of different sizes). An inverse Fisher transformation was then applied to give a pooled correlation coefficient. PCA was applied to the matrix of pooled correlation coefficients, giving us dietary patterns (linear combinations of standardised food intakes), which could be used in all the five centres. This meta-analytic approach to PCA has previously been applied in the field of psychiatry ${ }^{(22,23)}$.

\section{Data analysis}

We looked at whether characteristics of participants influenced rates of responding to the FFQ using logistic regression, with responding as the outcome, adjusting for centre. Social class was based on occupation using International Standard Classification of Occupations-88 codes $^{(24)}$. Subjects were categorised as never, ex- or current smokers based on questionnaire responses and were divided into four groups according to reported frequency of physical exercise ('How often do you usually exercise so much that you get out of breath or sweat?'): never; less than once a week; one to three times a week; or more than three times a week.

We used multivariable regression to investigate associations between the dietary patterns (in quintile groups) and respiratory outcomes at each centre. Logistic regression was used for asthma, negative binomial regression for symptom score and linear regression for BHR slope and $\mathrm{FEV}_{1}$. Analyses were adjusted for age, sex, social class, smoking status, exercise, BMI and quintiles of total energy intake. The effects of the dietary patterns were also adjusted for each other, 
because although principal components are uncorrelated, rotations (even orthogonal ones) can introduce correlations between the dietary patterns.

Regression results were pooled across centres using random effects meta-analysis, with a test for heterogeneity of regression coefficients ${ }^{(25)}$. Heterogeneity was summarised using the $I^{2}$ statistic $^{(26)}$.

\section{Statistical software}

Some analyses of the German data were carried out locally using SAS (SAS Institute, Cary, NC, USA). All other analyses were done with Stata 10 (Stata Corporation, College Station, TX, USA).

The present study was conducted according to the guidelines laid down in the Declaration of Helsinki and all procedures involving human participants were approved by the Bavarian General Medical Council in Germany, the Ipswich Hospital and Norfolk and Norwich Hospital ethics committees in the UK and the Regional Committee of Medical Research Ethics at the University of Bergen in Norway. Written informed consent was obtained from all the participants.

\section{Results}

Fig. 1 shows the numbers of people taking part, by centre. Clinical and questionnaire assessments were available for 1740 subjects. Complete FFQ data were provided by 1182 of these, but eight were excluded because they were at the extremes of the distribution of ratio of energy intake to expected BMR in their country (in Germany, there was one under-reporter (ratio $<0.59$ ) and one over-reporter $(>5.5)$, in the UK one under-reporter $(<0.44)$ and one overreporter $(>3.6)$, and in Norway two under-reporter $(<0.50)$ and two over-reporter $(>5 \cdot 2))$. The 1174 people who responded to the FFQ with a realistic energy intake $(35 \%$ of those contacted) ranged in age from 29 to 55 years. Those in a higher social class were more likely to be responders $(P<0.001)$, as were people who exercised more frequently $(P=0.012)$. Current smokers were less likely than ex- or never-smokers to respond $(P=0 \cdot 001)$. There was no evidence that age, sex or BMI were associated with responding. Of the
1174 responders, reported asthma was available for 1173, asthma score for 1160 and BHR slope for 906. Table 1 summarises total energy and macro-nutrient intakes in responders.

\section{Principal components analysis}

The scree plot from the PCA showed a clear break in the curve after two components, with no natural choice of any larger but still parsimonious number of components to extract. These two dietary patterns explained $11.2 \%$ of the variance in the FFQ data. Table 2 shows how individual foods were correlated with each of these patterns at the five centres. Although a pattern score is defined as the same weighted sum of standardised food intakes at each centre, correlations with individual foods may differ between the centres because of differences in local diets, and this table is a good way to judge the heterogeneity or homogeneity of dietary patterns. In our case, there was a close match between the centres in the foods which characterised each pattern. The first pattern was closely associated with sliced meat, beef, pork, bacon, sausage and fried egg/scrambled egg/omelette intake at all the centres and also with intake of potato or chips. Depending on the centre, it also correlated closely with bread, butter, biscuits and cakes. This pattern is referred to here, for conciseness, as the 'meat and potato' pattern. The second pattern was closely associated with intakes of several fruits at all the centres and less consistently with intakes of a number of vegetables and fish. This pattern is referred to here as the 'fish, fruits and vegetables' pattern.

\section{Dietary patterns and respiratory outcomes}

Fig. 2 shows the results of meta-analyses as forest plots. There was no overall evidence that the meat and potato pattern was associated with asthma $(P=0.90)$, symptom score $(P=0.58)$, BHR slope $(P=0.39)$ or $\mathrm{FEV}_{1}(P=0.74)$, and similarly no evidence that the fish, fruits and vegetables pattern was associated with asthma $(P=0 \cdot 26)$, symptom score $(P=0 \cdot 16)$, BHR slope $(P=0.89)$ or $\mathrm{FEV}_{1}(P=0 \cdot 19)$.

There was no evidence of heterogeneity across the centres in any of these effects, except in the case of the association

\begin{tabular}{|c|c|c|c|c|c|c|}
\hline & $\begin{array}{l}\text { Hamburg } \\
\text { (Germany) }\end{array}$ & $\begin{array}{c}\text { Erfurt } \\
\text { (Germany) }\end{array}$ & $\begin{array}{l}\text { Ipswich } \\
\text { (UK) }\end{array}$ & $\begin{array}{l}\text { Norwich } \\
\text { (UK) }\end{array}$ & $\begin{array}{l}\text { Bergen } \\
\text { (Norway) }\end{array}$ & Total \\
\hline $\begin{array}{l}\text { Contacted to take part } \\
\text { in ECRHS II }\end{array}$ & 900 & 731 & 448 & 473 & 835 & 3387 \\
\hline $\begin{array}{l}\text { Clinical and questionnaire } \\
\text { assessments }\end{array}$ & 303 & 287 & 297 & 257 & 596 & 1740 \\
\hline Complete FFO & $\stackrel{202}{1}$ & 188 & 144 & 97 & 551 & 1182 \\
\hline $\begin{array}{l}\text { Realistic total energy } \\
\text { intake }\end{array}$ & 201 & 187 & 143 & 96 & 547 & 1174 \\
\hline $\begin{array}{l}\text { Response rate } \\
\text { (\%; out of total contacted) }\end{array}$ & 22 & 26 & 32 & 20 & 66 & 35 \\
\hline
\end{tabular}

Fig. 1. Flow chart showing numbers of subjects in the study. ECRHS, European Community Respiratory Health Survey. 
Table 2. How correlates of dietary patterns vary between centres*

\begin{tabular}{|c|c|c|c|c|c|c|c|c|c|c|}
\hline \multirow[b]{3}{*}{ Food } & \multicolumn{10}{|c|}{ Centre } \\
\hline & \multicolumn{5}{|c|}{ Meat and potato pattern } & \multicolumn{5}{|c|}{ Fish, fruits and vegetables pattern } \\
\hline & G1 & G2 & UK1 & UK2 & $\mathrm{N}$ & $\mathrm{G} 1$ & G2 & UK1 & UK2 & $\mathrm{N}$ \\
\hline $\begin{array}{l}\text { Bread and rolls } \\
\text { Butter } \\
\text { Jam and marmalade }\end{array}$ & 0.34 & 0.33 & 0.31 & 0.32 & $\begin{array}{l}0.33 \\
0.30\end{array}$ & & & & & \\
\hline $\begin{array}{l}\text { Honey } \\
\text { Peanut butter }\end{array}$ & & & & & & 0.41 & 0.38 & & & \\
\hline Biscuits & 0.36 & & 0.38 & 0.38 & 0.35 & & & & & \\
\hline $\begin{array}{l}\text { Cakes, puddings, desserts } \\
\text { Donuts, pastries, tarts }\end{array}$ & 0.31 & $\begin{array}{l}0.37 \\
0.30\end{array}$ & & & 0.36 & & & & & \\
\hline $\begin{array}{l}\text { Yoghurt } \\
\text { Ice cream } \\
\text { Cream cheese } \\
\text { Cottage cheese }\end{array}$ & & & 0.34 & & 0.31 & & & 0.47 & & \\
\hline $\begin{array}{l}\text { Hard cheeses } \\
\text { Soft cheeses }\end{array}$ & & & 0.32 & 0.43 & & & & & & \\
\hline $\begin{array}{l}\text { Boiled egg } \\
\text { Fried/scrambled egg, omelette } \\
\text { Quiche }\end{array}$ & 0.34 & 0.37 & 0.45 & 0.31 & 0.51 & & & & & \\
\hline Sliced meat & 0.36 & 0.45 & 0.59 & 0.56 & 0.45 & & & & & \\
\hline Beef steak & 0.38 & 0.44 & 0.45 & 0.40 & 0.33 & & & & & \\
\hline Beef burger & 0.64 & 0.42 & 0.37 & 0.39 & 0.30 & & & & & \\
\hline Meat-minced, meat stew, casserole & 0.60 & 0.55 & 0.39 & 0.46 & 0.39 & & & & & \\
\hline Pork chops & 0.59 & 0.55 & 0.53 & 0.46 & 0.48 & & & & & \\
\hline Bacon & 0.44 & 0.40 & 0.42 & 0.69 & 0.55 & & & & & \\
\hline Poultry & 0.57 & 0.41 & 0.34 & & 0.44 & & & 0.30 & & \\
\hline Maized beef and luncheon meat & 0.42 & & & 0.36 & & & & & & \\
\hline Sausages & 0.40 & 0.50 & 0.53 & 0.55 & 0.49 & & & & & \\
\hline Liver & & 0.39 & 0.37 & 0.37 & & & & & & \\
\hline Pate & 0.36 & 0.33 & & 0.31 & 0.36 & & & & & \\
\hline $\begin{array}{l}\text { Fish fillets/cakes/fingers } \\
\text { Tinned fish }\end{array}$ & 0.31 & & & & & 0.32 & 0.34 & 0.43 & & 0.31 \\
\hline $\begin{array}{l}\text { Potato - boiled/mashed/baked } \\
\text { Chips }\end{array}$ & $\begin{array}{l}0.42 \\
0.30\end{array}$ & $\begin{array}{l}0.33 \\
0.33\end{array}$ & 0.33 & 0.34 & 0.40 & & & & 0.33 & \\
\hline Rice and rice dishes & & & & & 0.30 & 0.30 & 0.32 & & 0.34 & \\
\hline Soyat, quorn, bulgur, polenta & & & & & & & 0.44 & & 0.40 & \\
\hline Vegetarian paste & & & & & & 0.30 & 0.32 & & 0.34 & \\
\hline $\begin{array}{l}\text { Pizza } \\
\text { Soup }\end{array}$ & & 0.38 & & & & & & 0.44 & & \\
\hline Broccoli, cabbage, cauliflower & 0.30 & & & & & 0.38 & 0.33 & 0.48 & 0.68 & 0.53 \\
\hline Carrots & & & & & & 0.51 & 0.36 & 0.54 & 0.47 & 0.45 \\
\hline Garlic & & & & & & & 0.31 & 0.49 & 0.51 & \\
\hline Peas & 0.36 & & & & & & & & 0.34 & \\
\hline Peppers & & & & & & 0.63 & 0.37 & 0.47 & 0.41 & 0.31 \\
\hline Green beans & & & & & & & & 0.47 & 0.61 & \\
\hline Tomato & & & & & & 0.50 & 0.51 & 0.32 & 0.59 & 0.45 \\
\hline Bean sprouts & & & & & & & 0.31 & 0.31 & & \\
\hline Lentils, dahl, bean casserole & & & & & & & & 0.35 & 0.42 & \\
\hline Tomato ketchup & & & 0.31 & & 0.38 & & & & & \\
\hline Apple & & & & & & 0.45 & 0.42 & 0.40 & 0.53 & 0.48 \\
\hline Banana & & & & & & 0.35 & 0.38 & 0.51 & 0.53 & 0.43 \\
\hline Grapes & & & & & & 0.64 & 0.40 & & 0.62 & \\
\hline Kiwi, mango, pineapple & & & & & & 0.63 & 0.53 & 0.45 & 0.64 & 0.49 \\
\hline Orange & & & & & & 0.55 & 0.53 & 0.49 & 0.48 & 0.44 \\
\hline Pear & & & & & & 0.41 & 0.39 & 0.50 & 0.55 & 0.47 \\
\hline Peach and nectarine & & & & & & 0.42 & 0.31 & 0.39 & 0.54 & 0.33 \\
\hline Raspberries, red/blackcurrants & & & & & & & 0.33 & 0.35 & 0.47 & 0.35 \\
\hline Strawberries & & & & & & 0.46 & 0.43 & & 0.40 & 0.41 \\
\hline Tinned/stewed fruit & & & & & & 0.30 & & & & \\
\hline Breakfast cereals & & & & & & 0.48 & 0.41 & & & \\
\hline
\end{tabular}

Chocolate bars and cereal bars

Chocolate

Nuts

Orange juice

Other fruit juice 
Table 2. Continued

\begin{tabular}{|c|c|c|c|c|c|c|c|c|c|c|}
\hline \multirow[b]{3}{*}{ Food } & \multicolumn{10}{|c|}{ Centre } \\
\hline & \multicolumn{5}{|c|}{ Meat and potato pattern } & \multicolumn{5}{|c|}{ Fish, fruits and vegetables pattern } \\
\hline & G1 & G2 & UK1 & UK2 & $\mathrm{N}$ & G1 & G2 & UK1 & UK2 & $\mathrm{N}$ \\
\hline \multicolumn{11}{|l|}{ Fizzy drinks } \\
\hline Tea - black/green & & & & & & 0.30 & & & & \\
\hline Herbal tea & & & & & & & & & 0.39 & \\
\hline \multicolumn{11}{|l|}{ Coffee (not decaffeinated) } \\
\hline \multicolumn{11}{|l|}{ Decaffeinated coffee } \\
\hline Milk and milky drinks & & & & & 0.34 & & & & & \\
\hline \multirow{2}{*}{\multicolumn{11}{|c|}{ Cider and perry }} \\
\hline & & & & & & & & & & \\
\hline \multicolumn{11}{|l|}{ Wine } \\
\hline \multicolumn{11}{|l|}{ Fortified wine } \\
\hline Liqueurs and spirits & & 0.32 & & 0.30 & 0.36 & & & & & \\
\hline
\end{tabular}

G1, Hamburg, Germany; G2, Erfurt, Germany; UK1, Ipswich, UK; UK2, Norwich, UK; N, Bergen, Norway.

*Values are Pearson correlation coefficients. For clarity, only values $>0.30$ or $<-0.30$ are shown.

†Foods made with soya protein: soya cheese; tofu; textured vegetable protein.

between meat and potato pattern score and symptom score $\left(I^{2}=75 \% ; P=0.003\right)$. In this case, it was evident from a visual inspection that the two German centres had qualitatively different results to the others; in fact, when countries were (meta-) analysed separately, increased meat and potato intake was associated with a decrease in symptoms in Germany (ratio of mean number of symptoms per quintile $=0.81 ; 95 \%$ CI $0.68,0.97 ; P=0.025)$ but with an increase in symptoms in the UK (ratio per quintile $=1.34$; $95 \%$ CI $1.09,1.67 ; P=0.007$ ) and Norway (ratio per quintile $=1.24 ; 95 \%$ CI $1.00,1.55 ; P=0.051)$.

\section{Discussion}

We could not confirm any harmful or beneficial effects of fish, fruits and vegetable intake on asthma, though CI ruled out a reduction in the odds of current asthma of more than $7 \%$ per quintile of fish, fruits and vegetable consumption or a reduction in the mean number of asthma symptoms of more than $2 \%$ per quintile. Fish, fruits and vegetables are essential components of a Mediterranean diet, which other recent work has found to be associated with improved asthma control in adults $^{(27)}$, lower risk of current severe asthma in girls aged 6-7 years $^{(28)}$ and lower risk of allergic rhinitis in children aged 7-18 years $^{(29)}$. Fish in the diet is a source of $n-3$ fatty acids, which may compete with the pro-inflammatory properties of $n-6$ fatty acids ${ }^{(30,31)}$. Recent results from the Respiratory Health in Northern Europe study indicated that infrequent fish intake was associated with increased asthma symptoms ${ }^{(32)}$, but experimental support for this as a major influence on clinical disease is still weak ${ }^{(33)}$. Dietary antioxidants, of which fruits and vegetables should be a rich source, have also been hypothesised to be important in protecting against atopic disease ${ }^{(34)}$. Vitamin $\mathrm{E}$, in particular, has been associated in some studies with a reduction in atopy $^{(3)}$, though a trial of vitamin $\mathrm{E}$ supplementation in asthma failed to show an effect ${ }^{(35)}$.

The heterogeneous effect of the meat and potato pattern is not easy to explain. Patterns similar to this have often been labelled 'western' and are likely to represent a mixture of dietary components which may independently contribute to asthma risk $^{(5,6)}$. Heterogeneity in multi-centre studies can also suggest alternative explanations for apparent effects of diet observed in single centres, such as uncontrolled confounding, and would make us cautious of progressing to a trial ${ }^{(36)}$. Our study was cross-sectional, and a further possibility is reverse causation, people with asthma may alter their diet in a systematic way at a given centre, for example, to be more 'healthy'.

Note that our analysis gives us common dietary patterns (weighted sums of standardised food intakes) that we can investigate at every centre. However, if a dietary pattern is acting as a proxy for individual foods associated with asthma, then some heterogeneity in its effect might be due to heterogeneity in its associations with these foods. The greatest variation in the correlations of individual foods with the meat and potato pattern was for beef burger (high in Hamburg, low in Bergen), bacon (high in Norwich, low in Erfurt) and poultry (high in Hamburg, low in Norwich).

FFQ are widely used in epidemiological studies to investigate dietary intake of individuals and its association with diseases. FFQ are cost-effective tools to assess the usual current and past patterns of food intake over an extended period of time ${ }^{(37)}$. Estimates of the validity of our FFQ data, for Germany at least, were good, being in the same range as those reviewed by Willett ${ }^{(38)}$. In the UK, validity was based on just a single 24-h dietary recall, but correlations were still notably high at $0 \cdot 25-0 \cdot 31$, and we might reasonably expect that with multiple 24-h dietary recalls and adjustment for within-person variability, we would have observed correlations as good as those seen in Germany. 'True' validity may, in general, be worse than implied by studies using 24-h recall, because of correlated errors. This was the case for the EPIC-Norfolk FFQ, from which our FFQ was derived, for which estimates of $\mathrm{Na}$ and nitrogen intake correlated poorly with repeated 24-h urine measurements ${ }^{(39)}$. In Norway, we used a translation of the UK FFQ, but this included all the foods from the Norwegian EPIC FFQ ${ }^{(40,41)}$, so we believe it is unlikely to have missed much in the Norwegian diet (we note that the total energy intake calculated from the FFQ in Norway was, if anything, higher than in the UK (Table 1)). Using a direct translation of the UK FFQ had 
ES per quintile of dietary pattern scores

Asthma

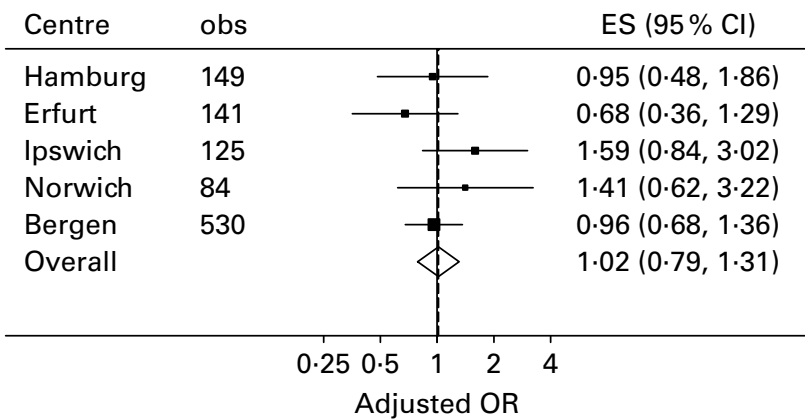

Symptom score

\begin{tabular}{lll|ll} 
Centre & obs & \multicolumn{3}{c}{ ES $(95 \% \mathrm{Cl})$} \\
\hline Hamburg & 196 & & $0.87(0.69,1.09)$ \\
Erfurt & 184 & & & $0.74(0.56,0.99)$ \\
Ipswich & 130 & & $1.42(1.07,1.88)$ \\
Norwich & 92 & & $1.25(0.90,1.74)$ \\
Bergen & 527 & & $1.24(1.00,1.55)$ \\
Overall & & & $1.07(0.84,1.36)$ \\
& & & & \\
\hline & & 0.5 & 1 & 2
\end{tabular}

Adjusted ratio of mean scores
Fish, fruits and vegetables
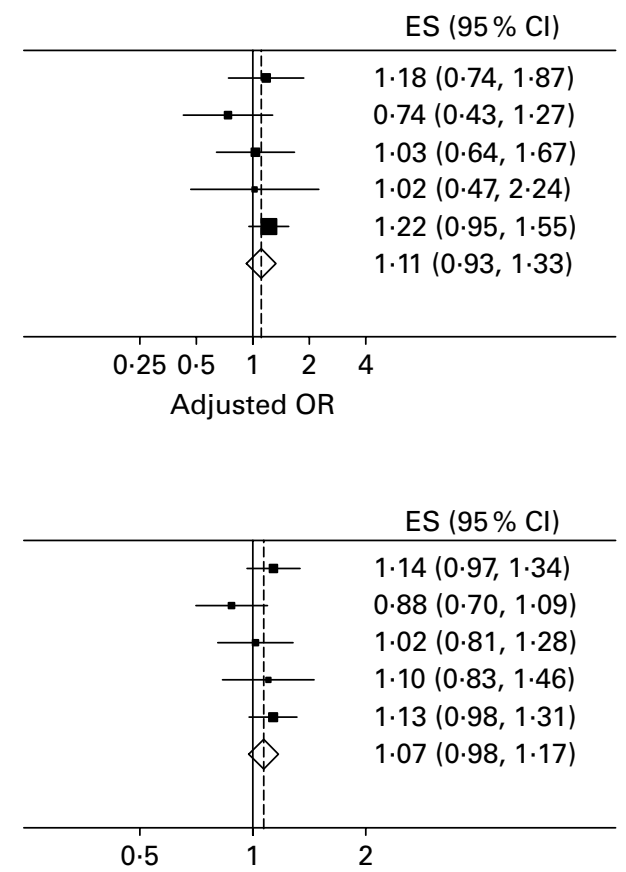

Adjusted ratio of mean scores

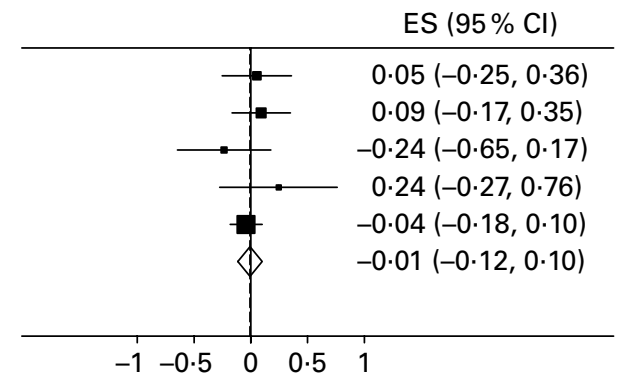

Adjusted regression coefficient

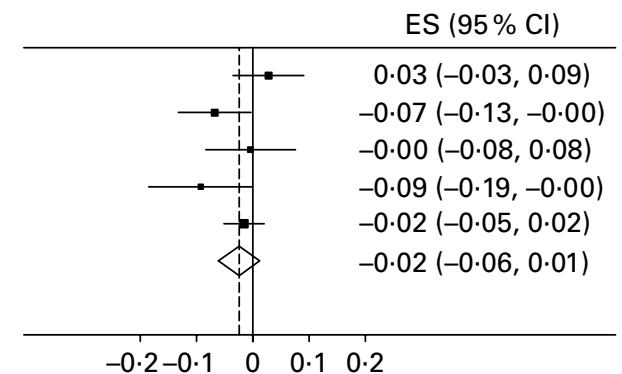

Adjusted regression coefficient
Adjusted regression coefficient ES $(95 \% \mathrm{Cl})$

\begin{tabular}{|c|c|c|}
\hline Centre & obs & $\mathrm{ES}(95 \% \mathrm{Cl})$ \\
\hline Hamburg & 195 & $0.00(-0.08,0.09)$ \\
\hline Erfurt & 184 & $-0.01(-0.10,0.07)$ \\
\hline Ipswich & 135 & $-0.01(-0.10,0.09)$ \\
\hline Norwich & 91 & $-0.01(-0.12,0.09)$ \\
\hline Bergen & 534 & $-0.00(-0.06,0.05)$ \\
\hline Overall & & $-0.01(-0.04,0.03)$ \\
\hline
\end{tabular}

$\mathrm{ES}(95 \% \mathrm{Cl})$

$0.15(-0.26,0.55)$

$0.33(-0.26,0.92)$

$-0.12(-0.32,0.08)$

$-0.08(-0.27,0.10)$

Fig. 2. Associations between the two dietary patterns and respiratory outcomes: results of meta-analyses. ES, effect size; BHR, bronchial responsiveness; $\mathrm{FEV}_{1}$, forced expiratory volume in $1 \mathrm{~s}$.

the great advantage of simplifying the pooling of data from Norway and the UK.

The poor response rates in our study were partly due to the time that had expired between the end of ECRHS-I and the recruitment of cohort members into ECRHS-II. Differences between response rates in different countries were also partly explained by differences in procedures. FFQ assessments in the UK were implemented much later than other 
assessments because the protocol had to be developed and approved separately, and the interval between the two clinic visits was up to 23 months (inter-quartile range 10-16 months) helping to explain the low rate of FFQ completion. In Norway, assessments were done in a single clinic visit. In Germany, participants were asked to complete the FFQ at home and return it by mail to reduce the burden placed on them in attending the clinic.

Methods for identifying dietary patterns, such as PCA, have proved a popular way to explore complex diet data in the last decade ${ }^{(4)}$. A meta-analytic approach to deriving dietary patterns across a number of centres has not, to our knowledge, been investigated before. This is, no doubt, partly because FFQ are often specific to a site, making it difficult to pool data. More work is needed to develop FFQ that allow directly comparable data to be collected in different countries. We have shown that the method can be successful in identifying common dietary patterns, as well as evidence for heterogeneity in the effects of those patterns. Heterogeneity in observational studies of diet can sometimes argue against progressing to trials.

In conclusion, we found no firm, consistent evidence for an association of diet with asthma, though CI appeared to rule out large beneficial effects of fish, fruits and vegetable consumption on current asthma or asthma symptoms. However, there are likely to be important, unmeasured confounders associated with dietary choices and observational studies of diet, particularly if they are cross-sectional, must be interpreted with caution.

\section{Acknowledgements}

The co-ordination of ECRHS-II was funded by the European Union (grant number FP5-QLK4-CT-1999-01 237). The fieldwork in the UK was supported by a grant from Asthma UK (formerly known as the National Asthma Campaign); that in Germany by Deutsche Forschungsgemeinschaft; that in Norway by the Norwegian Research Council, the Norwegian Asthma and Allergy Association, GlaxoWellcome AS and the Norway Research Fund. R. H. and V. G.-L. are supported by the Department of Health, UK (grant number DHTBXP05909). In addition, we acknowledge the contribution of the ECRHS-II steering committee, without whom the study would not be possible: Ursula Ackermann-Liebrich; Josep Antó; P. B.; Isa Cerveri; Sue Chinn; Roberto de Marco; Thorarinn Gislason; J. H.; Christer Janson; Deborah Jarvis; Jill Knox; Nino Künzli; Bénédicte Leyneart; Christina Luczynska; Françoise Neukirch; Jan Schouten; Jordi Sunyer; Cecilie Svanes; Paul Vermeire; Matthias Wjst. Contributions of the co-authors of this manuscript were as follows: J. H., E. O., S. S. and P. B. were involved in acquiring and managing the data; R. H. and I. B. conducted the data analysis; S. S. and V. G.-L. advised on nutritional analyses; R. H. wrote the first draft, and all the authors contributed to the final version. None of the authors has any conflicts of interest (personal, commercial, political, academic or financial).

\section{References}

1. Shaheen SO, Sterne JAC, Thompson RL, et al. (2001) Dietary antioxidants and asthma in adults - population-based casecontrol study. Am J Respir Crit Care Med 164, 1823-1828.
2. Hodge L, Salome CM, Peat JK, et al. (1996) Consumption of oily fish and childhood asthma risk. Med J Aust 164, 137-140.

3. Devereux G \& Seaton A (2005) Diet as a risk factor for atopy and asthma. J Allergy Clin Immunol 115, 1109-1117.

4. Newby PK \& Tucker KL (2004) Empirically derived eating patterns using factor or cluster analysis: a review. Nutr Rev 62, 177-203.

5. Varraso R, Fung TT, Hu FB, et al. (2007) Prospective study of dietary patterns and chronic obstructive pulmonary disease among US men. Thorax 62, 786-791.

6. Varraso R, Fung TT, Barr RG, et al. (2007) Prospective study of dietary patterns and chronic obstructive pulmonary disease among US women. Am J Clin Nutr 86, 488-495.

7. Butler LM, Koh WP, Lee HP, et al. (2006) Prospective study of dietary patterns and persistent cough with phlegm among Chinese Singaporeans. Am J Respir Crit Care Med 173, 264-270.

8. Takaoka M \& Norback D (2008) Diet among Japanese female university students and asthmatic symptoms, infections, pollen and furry pet allergy. Respir Med 102, 1045-1054.

9. Varraso R, Kauffmann F, Leynaert B, et al. (2009) Dietary patterns and asthma in the E3N study. Eur Resp J 33, 33-41.

10. European Community Respiratory Health Survey II Steering Committee (2002) The European Community Respiratory Health Survey II. Eur Respir J 20, 1071-1079.

11. Sunyer J, Pekkanen J, Garcia-Esteban R, et al. (2007) Asthma score: predictive ability and risk factors. Allergy 62, 142-148.

12. Chinn S, Arossa WA, Jarvis DL, et al. (1997) Variation in nebulizer aerosol output and weight output from the Mefar dosimeter: implications for multicentre studies. Eur Respir $J$ 10, 452-456.

13. Bohlscheid-Thomas S, Hoting I, Boeing H, et al. (1997) Reproducibility and relative validity of energy and macronutrient intake of a food frequency questionnaire developed for the German part of the EPIC project (European Prospective Investigation into Cancer and Nutrition). Int J Epidemiol 26, S71-S81.

14. Food Standards Agency (1993) Food Portion Sizes, 2nd ed. Norwich: HMSO.

15. Federal Institute for Health Protection of Consumers (BgVV) (1999) Der Bundeslebensmittelschlussel (BLS II.3) (The Bundeslebensmittelschlussel (BLS II.3))/The German Food Code and Nutrient Database. Berlin: BgVV.

16. Food Standards Agency (2002) McCance and Widdowson's the Composition of Foods, 6th ed. Cambridge: Royal Society of Chemistry.

17. Norwegian Food Safety Authority, Directorate for Health and Social Affairs, and University of Oslo (2006) http:// matportalen.no/matvaretabellen

18. Department of Health (1991) Dietary Reference Values for Food Energy and Nutrients for the United Kingdom. London: HMSO.

19. Welch AA, Luben R, Khaw KT, et al. (2005) The CAFE computer program for nutritional analysis of the EPIC-Norfolk food frequency questionnaire and identification of extreme nutrient values. J Hum Nutr Diet 18, 99-116.

20. McCann SE, Marshall JR, Brasure JR, et al. (2001) Analysis of patterns of food intake in nutritional epidemiology: food classification in principal components analysis and the subsequent impact on estimates for endometrial cancer. Public Health Nutr 4, 989-997.

21. Rosenthal R (1991) Meta-analytic Procedures for Social Research, revised ed., pp. 87. London: Sage.

22. Smith DA, Mar CM \& Turoff BK (1998) The structure of schizophrenic symptoms: a meta-analytic confirmatory factor analysis. Schizophr Res 31, 57-70.

23. Grube BS, Bilder RM \& Goldman RS (1998) Meta-analysis of symptom factors in schizophrenia. Schizophr Res 31, 113-120. 
24. International Labour Office (1991) International Standard Classification of Occupations (ISCO-88). Geneva: International Labour Organisation.

25. DerSimonian R \& Laird N (1986) Meta-analysis in clinical trials. Control Clin Trials 7, 177-188.

26. Higgins JPT, Thompson SG, Deeks J, et al. (2003) Measuring inconsistency in meta-analyses. BMJ 327, 557-560.

27. Barros R, Moreira A, Fonseca J, et al. (2008) Adherence to the Mediterranean diet and fresh fruit intake are associated with improved asthma control. Allergy 63, 917-923.

28. Garcia-Marcos L, Canflanca IM, Garrido JB, et al. (2007) Relationship of asthma and rhinoconjunctivitis with obesity, exercise and Mediterranean diet in Spanish schoolchildren. Thorax 62, 503-508.

29. Chatzi L, Apostolaki G, Bibakis I, et al. (2007) Protective effect of fruits, vegetables and the Mediterranean diet on asthma and allergies among children in Crete. Thorax 62, 677-683.

30. Black PN \& Sharpe S (1997) Dietary fat and asthma: is there a connection? Eur Respir J 10, 6-12.

31. Sausenthaler S, Koletzko B \& Heinrich J (2006) Dietary fat intake and allergic diseases. Curr Nutr Food Sci 2, 351-359.

32. Laerum BN, Wentzel-Larsen T, Gulsvik A, et al. (2007) Relationship of fish and cod oil intake with adult asthma. Clin Exp Allergy 37, 1616-1623.

33. Thien FCK, Woods R \& De Luca S, et al. (2002) Dietary marine fatty acids (fish oil) for asthma in adults and children Cochrane Database of Systematic Reviews, issue 2,
CD001283. http://www.mrw.interscience.wiley.com/cochrane/ clsysrev/articles/CD001283/frame.html

34. Seaton A, Godden DJ \& Brown K (1994) Increase in asthma - a more toxic environment or a more susceptible population? Thorax 49, 171-174.

35. Pearson PJK, Lewis SA, Britton J, et al. (2004) Vitamin E supplements in asthma: a parallel group randomised placebo controlled trial. Thorax 59, 652-656.

36. Burney P, Potts J, Makowska J, et al. (2008) A case-control study of the relation between plasma selenium and asthma in European populations: a $\mathrm{GA}^{2} \mathrm{LEN}$ project. Allergy 63, $865-871$.

37. Cade JE, Burley VJ, Warm DL, et al. (2004) Food-frequency questionnaires: a review of their design, validation and utilisation. Nutr Res Rev 17, 5-22.

38. Willett WC (1990) Nutritional Epidemiology. Oxford: Oxford University Press.

39. Day NE, McKeown N, Wong MY, et al. (2001) Epidemiological assessment of diet: a comparison of a 7-day diary with a food frequency questionnaire using urinary markers of nitrogen, potassium and sodium. Int J Epidemiol 30, 309-317.

40. Engeset D, Alsaker E, Ciampi A, et al. (2005) Dietary patterns and lifestyle factors in the Norwegian EPIC cohort: the Norwegian Women and Cancer (NOWAC) study. Eur J Clin Nutr 59, 675-684.

41. The Norwegian Women and Cancer Study (NOWAC), http:// uit.no/kk/Questionnaire/ (accessed August 2009).

\section{Appendix: Food items in each of the food groups analysed}

Food items on FFQ

\begin{tabular}{|c|c|c|}
\hline \multirow[b]{2}{*}{ Food groups analysed } & \\
\hline & UK/Norway & Germany \\
\hline \multirow[t]{5}{*}{ Bread and rolls } & Bread and toast & Rye bread, rye-wheat bread \\
\hline & Bread rolls, hamburger rolls, French & White bread, wheat bread \\
\hline & bread, etc & Wholemeal bread \\
\hline & & White rolls \\
\hline & & Brown and wholemeal rolls \\
\hline \multirow[t]{2}{*}{ Butter } & Butter spread on bread, toast, rolls, & Butter \\
\hline & crackers & Butter, half-fat \\
\hline Jam and marmalade & Jam, marmalade & Marmalade, jam and jelly \\
\hline Honey & Honey & Honey \\
\hline \multirow[t]{2}{*}{ Peanut butter } & Peanut butter & Chocolate and nut spread, chocolate \\
\hline & Chocolate, chocolate and nut spreads & spread, peanut butter \\
\hline \multirow[t]{3}{*}{ Biscuits } & Chocolate biscuits & Crackers, biscuits \\
\hline & Plain biscuits & \\
\hline & Sandwich or cream biscuits & \\
\hline \multirow[t]{6}{*}{$\begin{array}{l}\text { Cakes, puddings and } \\
\text { desserts }\end{array}$} & $\begin{array}{l}\text { Cakes (sponge, gateau, chocolate, } \\
\text { ginger, etc) }\end{array}$ & $\begin{array}{l}\text { Fruit cake (e.g. apple cake, rhubarb cake) } \\
\text { Pound cake, quick bread, ring-shaped }\end{array}$ \\
\hline & Fruit cake & cake \\
\hline & $\begin{array}{l}\text { Puddings and desserts (cheese cake, } \\
\text { fruit pie, jelly, rice pudding, etc) }\end{array}$ & $\begin{array}{l}\text { Layer cake, cream cake, flan (including } \\
\text { cheesecake) }\end{array}$ \\
\hline & & Yeast pastry (e.g. crumb cake, Stollen) \\
\hline & & $\begin{array}{l}\text { Sweet casseroles (e.g. rice pudding, } \\
\text { curd casserole) }\end{array}$ \\
\hline & & $\begin{array}{l}\text { Pudding, fruit quark, sundae or other } \\
\text { sweet food }\end{array}$ \\
\hline $\begin{array}{l}\text { Donuts, pastries and } \\
\text { tarts }\end{array}$ & $\begin{array}{l}\text { Donuts, custard tarts, and other } \\
\text { pastries or tarts }\end{array}$ & Buns (e.g. apple turnover, cinnamon bun) \\
\hline Yoghurt & $\begin{array}{l}\text { Yoghurt, thick and creamy } \\
\text { Yoghurt, low fat } \\
\text { Yoghurt, low energy } \\
\text { Yoghurt, Greek }\end{array}$ & Yoghurt \\
\hline Ice cream & Ice cream & Ice cream \\
\hline Cream cheese & Cream cheese, other cheese spread & Cream cheese \\
\hline Cottage cheese & Cottage cheese & Quark, herb quark (but not fruit quark) \\
\hline
\end{tabular}


Appendix: Continued

\begin{tabular}{|c|c|c|}
\hline \multirow[b]{2}{*}{ Food groups analysed } & \multicolumn{2}{|c|}{ Food items on FFQ } \\
\hline & UK/Norway & Germany \\
\hline Hard cheeses & Cheddar cheese and other hard cheeses & $\begin{array}{l}\text { Gouda, Emmental, Tilsiter and other } \\
\text { hard cheese }\end{array}$ \\
\hline Soft cheeses & Brie cheese and other soft cheeses & $\begin{array}{l}\text { Soft cheese } \\
\text { Camembert, brie, gorgonzola and } \\
\text { other soft cheese }\end{array}$ \\
\hline Boiled egg & Boiled or poached egg & Hard- and soft-boiled egg \\
\hline $\begin{array}{l}\text { Fried egg, scrambled egg } \\
\text { and omelette }\end{array}$ & $\begin{array}{l}\text { Omelette or scrambled egg } \\
\text { Fried egg }\end{array}$ & Fried egg, scrambled egg, omelette \\
\hline Quiche & Quiche and other savoury flans & Quiche, onion pancakes, bacon cakes \\
\hline Sliced meat & $\begin{array}{l}\text { Sliced meat (roast or boiled) - beef, } \\
\text { lamb or pork } \\
\text { Ham }\end{array}$ & $\begin{array}{l}\text { Ham, cold smoked pork loin, cold roast meat } \\
\text { Roast beef, boiled beef } \\
\text { Roast pork }\end{array}$ \\
\hline Beef steak & Beef steak & Beef steak, fillet, loin \\
\hline Beef burger & Beef burger (with or without bun) & Beef burger, meatloaf \\
\hline $\begin{array}{l}\text { Minced meat, meat stew } \\
\text { and casserole }\end{array}$ & $\begin{array}{l}\text { Beef minced with gravy, chilli con } \\
\text { carne, bolognese sauce, etc } \\
\text { Meat stew, casserole, mince, curry }\end{array}$ & $\begin{array}{l}\text { Minced meat in sauce, hash } \\
\text { Stuffed roll of beef } \\
\text { Beef stew, beef cut in pieces } \\
\text { Pork stew, pork cut in pieces } \\
\text { Boiled pork, knuckle of pork }\end{array}$ \\
\hline Pork chops & Pork chops & $\begin{array}{l}\text { Pork cutlet, chop, steak, fillet, loin } \\
\text { Smoked pork loin, pork ribs }\end{array}$ \\
\hline Bacon & Bacon & Pork belly \\
\hline Poultry & $\begin{array}{l}\text { Chicken, turkey, other poultry, roast } \\
\text { Chicken, turkey, other poultry in sauce }\end{array}$ & $\begin{array}{l}\text { Roast chicken } \\
\text { Turkey strips, turkey in breadcrumbs, } \\
\text { chicken fricassee, duck, goose, } \\
\text { or other poultry }\end{array}$ \\
\hline $\begin{array}{l}\text { Corned beef and } \\
\text { luncheon meat }\end{array}$ & Corned beef or luncheon meat & $\begin{array}{l}\text { Salami, hard Mettwurst } \\
\text { Bierschinken, Lyoner, Jagdwurst, } \\
\text { Schinkenwurst, or other cold meats }\end{array}$ \\
\hline Sausages & Sausages - beef, pork, other meat & $\begin{array}{l}\text { Bratwurst } \\
\text { Wienerle, Frankfurter, Bockwurst, } \\
\text { Knackwurst, sausage loaf }\end{array}$ \\
\hline Liver & Liver, kidney and other offal & Liver \\
\hline Pâté & Pâté & $\begin{array}{l}\text { Liverwurst } \\
\text { Teewurst, soft Mettwurst, or other } \\
\text { spreadable sausage }\end{array}$ \\
\hline $\begin{array}{l}\text { Fish fillets, fish cakes } \\
\text { and fish fingers }\end{array}$ & $\begin{array}{l}\text { White fish - not coated (cod, halibut, } \\
\text { haddock, whiting, plaice, sole, etc) } \\
\text { White fish - in batter or crumbs (cod, } \\
\text { haddock, plaice, etc) } \\
\text { Oily fish (herring, mackerel, salmon - } \\
\text { not tinned, trout, kippers, etc) } \\
\text { Fish cakes, fish fingers }\end{array}$ & $\begin{array}{l}\text { Fish (e.g. natural or breaded fillet, } \\
\text { fish fingers) }\end{array}$ \\
\hline Tinned fish & $\begin{array}{l}\text { Tinned fish (sardines, pilchards, tuna, } \\
\text { salmon, etc) }\end{array}$ & $\begin{array}{l}\text { Tinned fish, smoked fish (e.g. tuna, } \\
\text { pickled herring, salmon, smoked trout) }\end{array}$ \\
\hline $\begin{array}{l}\text { Potato - boiled, mashed } \\
\text { or baked }\end{array}$ & $\begin{array}{l}\text { Potato, boiled or mashed } \\
\text { Potato, baked in jacket }\end{array}$ & $\begin{array}{l}\text { Boiled potatoes, jacket potato as side } \\
\text { dish } \\
\text { Mashed potato }\end{array}$ \\
\hline Chips & Chips & Chips, potato croquettes \\
\hline Rice and rice dishes & $\begin{array}{l}\text { Plain rice } \\
\text { Rice dishes (e.g. pilau, risotto, paella) }\end{array}$ & $\begin{array}{l}\text { Rice (e.g. risotto, paella,... as a main } \\
\text { course or as a side dish) }\end{array}$ \\
\hline $\begin{array}{l}\text { Foods made with soya protein, } \\
\text { quorn, bulgur, polenta }\end{array}$ & $\begin{array}{l}\text { Soya cheese } \\
\text { Quorn dishes } \\
\text { Textured vegetable protein, Sosmix, } \\
\text { vegetable burger mix, soya sausage } \\
\text { Bulgur wheat }\end{array}$ & $\begin{array}{l}\text { Vegetarian foods (e.g. polenta, } \\
\text { Getreidebratlinge, soya mince, tofu) }\end{array}$ \\
\hline Vegetarian paste & $\begin{array}{l}\text { Vegetable pâté } \\
\text { Nut pâté }\end{array}$ & Vegetarian paste \\
\hline Pizza & $\begin{array}{l}\text { Pizza with meat } \\
\text { Pizza with vegetables }\end{array}$ & Pizza \\
\hline Soup & $\begin{array}{l}\text { Packet soups } \\
\text { Low energy soups } \\
\text { Cream soups (tinned or fresh) } \\
\text { Other soups (tinned or fresh) }\end{array}$ & Soup \\
\hline
\end{tabular}


Appendix: Continued

\begin{tabular}{|c|c|c|}
\hline \multirow[b]{2}{*}{ Food groups analysed } & \multicolumn{2}{|c|}{ Food items on FFQ } \\
\hline & UK/Norway & Germany \\
\hline $\begin{array}{l}\text { Broccoli, cabbage } \\
\text { and cauliflower }\end{array}$ & $\begin{array}{l}\text { Broccoli } \\
\text { Savoy cabbage, spinach, spring } \\
\text { greens, turnip tops, etc } \\
\text { White cabbage } \\
\text { Cauliflower }\end{array}$ & $\begin{array}{l}\text { Cauliflower, red cabbage, white } \\
\text { cabbage, kohlrabi, broccoli, and } \\
\text { other varieties of cabbage } \\
\text { Spinach }\end{array}$ \\
\hline Carrots & Carrot (raw or cooked) & $\begin{array}{l}\text { Raw carrots } \\
\text { Cooked carrots }\end{array}$ \\
\hline Garlic & Garlic & Garlic, fermented/roasted \\
\hline Peas & Peas & Green peas \\
\hline Peppers & Peppers (green, red, yellow, orange) & $\begin{array}{l}\text { Raw pepper } \\
\text { Cooked pepper }\end{array}$ \\
\hline Green beans & $\begin{array}{l}\text { Runner beans, green beans, mange } \\
\text { tout, sugar snaps, other green beans }\end{array}$ & Green beans \\
\hline Tomato & Tomato (raw, cooked, sauce) & $\begin{array}{l}\text { Raw tomato in summer } \\
\text { Raw tomato in winter } \\
\text { Cooked tomato, tomato sauce }\end{array}$ \\
\hline Bean sprouts & Bean sprouts & Bean sprouts \\
\hline $\begin{array}{l}\text { Lentils, dahl and mixed } \\
\text { bean casserole }\end{array}$ & $\begin{array}{l}\text { Lentils, dahl } \\
\text { Mixed bean casserole }\end{array}$ & Lentil stew, pea stew, bean stew \\
\hline Tomato ketchup & Tomato ketchup & Ketchup \\
\hline Apple & Apple & $\begin{array}{l}\text { Apple (summer/autumn) } \\
\text { Apple (winter/spring) }\end{array}$ \\
\hline Banana & Banana & $\begin{array}{l}\text { Banana (summer/autumn) } \\
\text { Banana (winter/spring) }\end{array}$ \\
\hline Grapes & Grapes & Grapes \\
\hline Kiwi, mango and pineapple & $\begin{array}{l}\text { Kiwi } \\
\text { Mango } \\
\text { Pineapple }\end{array}$ & $\begin{array}{l}\text { Kiwi, fresh pineapple, mango } \\
\text { (summer/autumn) } \\
\text { Kiwi, fresh pineapple, mango } \\
\text { (winter/spring) }\end{array}$ \\
\hline Orange & Orange & $\begin{array}{l}\text { Orange, grapefruit } \\
\text { Mandarin orange }\end{array}$ \\
\hline Pear & Pear & Pear \\
\hline Peach and nectarine & Nectarines peaches & Peach, nectarine \\
\hline $\begin{array}{l}\text { Raspberries, red currants } \\
\text { and blackcurrants }\end{array}$ & $\begin{array}{l}\text { Raspberries } \\
\text { Red or black currants }\end{array}$ & $\begin{array}{l}\text { Blackcurrants, raspberries, blackberries, } \\
\text { or other berries }\end{array}$ \\
\hline Strawberries & Strawberries & Strawberries \\
\hline Tinned or stewed fruit & $\begin{array}{l}\text { Canned or stewed fruit (not including } \\
\text { dried fruit) }\end{array}$ & Stewed fruit, tinned fruit \\
\hline Breakfast cereals & Breakfast cereals & $\begin{array}{l}\text { Cereal flakes, grains, muesli } \\
\text { Cornflakes etc }\end{array}$ \\
\hline $\begin{array}{l}\text { Chocolate bars and } \\
\text { cereal bars }\end{array}$ & $\begin{array}{l}\text { Chocolate bars (e.g. Mars, Twix) } \\
\text { Cereal bars, flapjacks } \\
\text { Fruit bar }\end{array}$ & Break-time snacks (e.g. Mars, cereal bar) \\
\hline Chocolate & $\begin{array}{l}\text { Milk chocolate bar } \\
\text { Plain chocolate bar }\end{array}$ & Chocolate \\
\hline Nuts & $\begin{array}{l}\text { Peanuts } \\
\text { Pistachios } \\
\text { Cashews } \\
\text { Almonds } \\
\text { Walnuts, pecans } \\
\text { Mixed nuts and raisins }\end{array}$ & Nuts (e.g. peanuts, walnuts, Brazil nuts) \\
\hline Orange juice & Orange juice (pure fruit juice) & Orange juice, grapefruit juice \\
\hline Other fruit juice & Other fruit juice (pure fruit juice) & $\begin{array}{l}\text { Apple juice } \\
\text { Grape juice, cherry juice, pineapple juice } \\
\text { or other fruit juice } \\
\text { Multivitamin juice }\end{array}$ \\
\hline Fizzy drinks & $\begin{array}{l}\text { Fizzy drinks (coke, lemonade, etc - } \\
\text { not diet drinks) } \\
\text { Low energy/diet drinks }\end{array}$ & $\begin{array}{l}\text { Lemonade } \\
\text { Cola }\end{array}$ \\
\hline Tea - black and green & $\begin{array}{l}\text { Tea, Indian } \\
\text { Tea, Chinese (green tea) }\end{array}$ & Black tea, green tea \\
\hline Herbal tea & Tea, herbal & Fruit tea, herb tea \\
\hline Coffee (not decaffeinated) & $\begin{array}{l}\text { Coffee, instant } \\
\text { Coffee, fresh }\end{array}$ & Coffee with caffeine \\
\hline Decaffeinated coffee & Coffee, decaffeinated & Decaffeinated coffee \\
\hline
\end{tabular}


Appendix: Continued

\begin{tabular}{lll}
\hline & & Food items on FFQ \\
\cline { 2 - 3 } Food groups analysed & UK/Norway & Germany \\
\hline Milk and milky drinks & $\begin{array}{l}\text { Plain milk to drink } \\
\text { Hot chocolate, cocoa }\end{array}$ & $\begin{array}{c}\text { Milk, milky drink (e.g. cocoa, but not } \\
\text { including milk with coffee) }\end{array}$ \\
& Horlicks, Ovaltine, Bournvita, etc & \\
Beer & Low energy milky drinks & Beer \\
Cider and perry & Beer, lager & Alcohol made with fruit, e.g. cider, most \\
Wine & Cider, perry & wine \\
& Red wine & Sparkling wine \\
Fortified wine & White wine & Rosé wine \\
Liqueurs and spirits & Fortified wines (sherry, port, etc) & Aperitifs, dessert wine, fortified wine \\
& Liqueurs & (e.g. sherry, port)
\end{tabular}

